\title{
7. Female Expatriates: Towards a More Inclusive View
}

\author{
Kate Hutchings and Snejina Michailova
}

\section{INTRODUCTION}

If we look to hunter gatherer societies, which are essentially the genetic result of ten thousand years ago, and we haven't evolved much since ... women are by necessity designed for and good at child-bearing and looking after relationships in a family ... in ancient societies it was the men that were out hunting and banding together to make sure they led the group and kept out outsiders ... you still see this kind of male bonding in the board rooms of companies today.

Clarke, cited in Gunn, 2015

Contentious? Yes. The words of an anthropologist? No. They are in fact the words of Christopher Clarke, president and chief executive of Boydon Global Executive Search, an executive recruitment firm with offices in over 40 countries throughout Europe, America, and Asia. Gunn (2015) argues that the basis of Clarke’s argument draws on evolutionary psychology, which is a growing movement among psychologists and involves the study of how human minds have evolved, and the traces left by that evolution.

Clarke goes on to say women are also skilled at trading and that in developing societies it is evident women continue to do the trading at the markets. As strong commercial skill has evolved, he suggests that companies need a better understanding of relationships and wider management through teams rather than through dominant male hierarchies. Further, Clarke points out that women care about relationships a lot more than men do, which makes them better at management because they are better at recognizing emotions, voracity and other people’s needs. Gunn (2015) says that Clarke suggests this makes women better at working in teams. Yet, she also points out that Clarke argues it is generally more difficult for a female to sever the relationships she 
has established and take-off for another country. If what Clarke says is true, while women may have the qualities of managing relationships and team focus that global organizations need to succeed (particularly given increasingly intercultural workplaces), it may be more difficult for women to engage in a mobile world of work because of family commitments.

Though traditionally international work meant relocating to another country for several years, new forms of global mobility might suggest greater flexibility for people across the globe to engage in international work and for women, especially, to allow them to balance work and family responsibilities. Research has found women may choose to self-initiate international careers (including managing their own businesses) in preference to taking organizational assignments (Tharenou, 2009). Also, women may find newer forms of international work which involve regular travel or short-term project work provide better options for managing their family and work commitments than do traditional, long-term assignments (Hutchings, Lirio and Metcalfe, 2012). Despite such expanding opportunities though, women continue to remain largely underrepresented amongst expatriates. In 2015 Brookfield’s Global Relocation Trends Survey Report (Brookfield Global Relocation Services, 2015) found women comprise only $19 \%$ of international assignees (a figure lower than the 23\% recorded ten years previously). Moreover, single women without children and women from developing countries are even more under-represented.

Within this chapter we explore the stream of research, commencing in the late 1970s, which has studied the reasons why women may be under-represented amongst those who expatriate in myriad forms. Just as Clarke suggested that the need to sever relationships might be a factor in women's reluctance to relocate internationally, 
researchers have also referred to women's own lack of interest in relocating, often due to family reasons (e.g. Dupuis, Haines and Saba, 2008; Fischlmayr and Kollinger, 2010; Mäkelä, Suutari and Mayerhofer, 2011; Tharenou, 2009). Other researchers have considered whether there are additional barriers/constraints for women relocating internationally. These include: organizational reticence to select women (e.g. Adler, 1984a; 1984b; 2002, Harris, 1995; 2001; Harris and Brewster, 1999; Insch, McIntyre and Napier, 2008); lack of support in organizations for women in international assignments (e.g. Linehan, Scullion and Walsh, 2001; Linehan and Scullion, 2008; Selmer and Leung, 2002); the likelihood of non-acceptance of women managers in certain foreign locations (e.g. Caligiuri and Tung, 1999; Hutchings, Michailova and Harrison, 2013; Napier and Taylor, 2011; Stalker and Mavin, 2012; Traavik and Richardsen, 2010); and more recently, the impact of national societal and cultural values (e.g. Hutchings, Lirio and Metcalfe, 2011; Hutchings, Metcalfe and Cooper, 2010; Hutchings and Michailova, 2014; Hutchings et al., 2015; Shortland, 2009).

Though much of the research about female expatriates has examined organizationally-assigned expatriates, within recent years this literature has expanded beyond examinations of just long-term organizational postings to also investigate women who self-initiate (Tharenou, 2009), and women who either self-initiate or accept organizational positions which involve undertaking international travel or components of international work within domestic jobs (Fischlmayr and Puchmüller, 2016; Hutchings et al., 2012; Tharenou, 2006). Further, recently consideration has been given to specific groups of non-traditional female expatriates such as lesbian expatriates (Gedro, 2010; McPhail, McNulty and Hutchings, 2016) and single parent expatriates (McNulty, 2015). While almost forty years of research on female expatriates has 
broadened our knowledge of factors that may limit women in expatriating, our analysis suggests that there are categories of female expatriates that have not been sufficiently explored within the international management literature in general and the expatriation literature in particular, but which deserves closer attention.

This chapter draws on our thinking developed over the course of ten years researching female expatriates. Though we have researched women from (and expatriating to) developing countries, our own research has evolved to examine and highlight the need for more research on women from a wider range of countries, different organizational types, and different family arrangements. In this chapter we refer to our own research, and that of others, about female expatriates to provide an understanding of how the field has evolved and how it needs to continue to develop. While earlier reviews of the literature on female expatriates have examined barriers to women's international relocation (be it organizational or self-initiated), our chapter adds insights in also reviewing very recent research that considers the impact of national culture on women’s international careers and non-traditional female expatriates. Moreover, we provide a detailed critique of the research in respect to the methodological and theoretical underpinnings and suggest theories that might be used in future research. In the following sections we: define female expatriates; identify trends and examine methods and theories used within the research; explore the key themes which have been considered in the research; and critique the contributions as well as limitations in the research. Moreover, we suggest directions for scholarly work in some areas that have been particularly neglected but are critical for researchers and organizations.

\section{DEFINITIONS}


For the purposes of this chapter we define female expatriates broadly as including any female (either legally- or self-identified) who leaves her country of origin/country of residence to work in another country for a fixed or indefinite period of time. This definition includes organizationally-assigned expatriates (OEs), self-initiated expatriates (SIEs), those on long-term or short-term/project work as well as those involved in international commuter and frequent flyer roles. The definition excludes migrants and permanent residents who (seek to) permanently relocate. Within the extant literature some researchers refer to women in international management; a term which has sometimes been used interchangeably with female expatriates and reflects that some of the early research did focus specifically on women who expatriate into managerial or executive-level roles in other countries in the employ of multinational corporations (MNCs). We believe the term women in international management should be used more broadly than has occurred in the past to encompass women from a more diverse range of countries, industries and sectors and who work domestically in international organizations (see also Hutchings and Michailova, 2014). In using the term 'female expatriates' herein we seek to discuss women who relocate abroad for all types/levels of positions, in a range of industries, and who work across sectors including business organizations, government organizations, non-government organizations (NGOs), and not-for-profit organizations.

\section{THE STATE OF PLAY}

Academic as well as practitioner-oriented publications discussing females in international management and expatriate roles were first noted in the 1970s. In 1979 Adler asked: Where are the women in international management? In her subsequent landmark research Adler (1984a; 1984b) studied perceptions of why women may be 
underrepresented amongst international managers. She investigated three possible barriers including: (1) foreigner prejudice (or perceptions that women would experience prejudice in foreign locations); (2) organizational resistance to selecting women as international managers; and, (3) whether women had a lack of interest in taking international management roles. Since then a large number of researchers (as referred to in our later section about key themes in prior research) have continued to examine whether these barriers exist and studies have included both women expatriates and women professionals working domestically who have not yet undertaken international work. Moreover, as the nature of international work has evolved beyond long-term assignments, studies examining women's continued under-representation in international management roles have expanded to include important examinations of women (and the role of gender) in self-initiated expatriation (Selmer and Lauring, 2011; Stalker and Mavin, 2011; Tharenou, 2009) as well as women who work internationally on short-term, project-based and frequent flyer assignments (Fischlmayr and Puchmüller, 2016; Hutchings et al., 2012; Mäkelä et al., 2015). The research has also developed to consider not just women who have management and executive roles, but also women who have sojourned overseas for lower level positions. Further, though the research has overwhelmingly focused on studies of women working in corporations, more recent research has begun to explore women working in the non-corporate world (e.g., Davoine, Ravasi, Salamin and Cudré-Mauroux, 2013; Fisher, Hutchings and Pinto, 2015). Thus the research on female expatriates could be broadly considered to constitute a discussion of women's international work and careers rather than international management roles specifically. The field continues to attract significant attention and remains an important area of enquiry. This is not surprising given 
organizations' competitiveness depends upon attracting and retaining the best human resources and that women constitute approximately half of the world's available talent.

\section{Theories, Methodologies and Trends in the Existing Literature}

We undertook an analysis of literature which has been published on female expatriates since the late 1970s in order to identify trends, frameworks and/or theories utilised within the research as well as methodological approaches. It was not our intention to undertake a systematic review of the literature or to refer to every study ever undertaken on female expatriates but rather we have selected, based on our prior research and knowledge of the field, papers which address the key themes discussed within the literature and highlight the (albeit somewhat limited) diversity of women and situations examined within this research.

\section{Theories}

We note that existing studies have primarily relied on streams of literature, frameworks, and models rather than formal theories. These streams of literature include broad areas such as: learning (Stalker and Mavin, 2011); networking (Shortland, 2011); careers/career development (Selmer and Leung, 2002; Traavik and Richardsen, 2010; Vance and McNulty, 2014); work/life balance (Mäkelä et al., 2011; Mäkelä et al., 2015); and ethics (Tharenou, 2009). Other more expatriate-focused streams of literature are also used as a basis for discussion including: adjustment (see, for example, Caligiuri, Joshi and Lazarova, 1999; Fischlmayr and Kollinger 2010; Fisher et al., 2015; Haslberger, Hippler and Brewster 2015; Mathur-Helm, 2002; Salamin and Davoine, 2015); cultural distance (Dupuis et al., 2008); expatriation (Gedro, 2010); expatriate failure (Shen and Jiang, 2015); or female expatriation which builds on Adler’s (1984a; 1984b, 1987; 1994) research (see for example, Caliguiri and Cascio, 
1998; Harris 1995; Hutchings, French and Hatcher, 2008; Hutchings, Metcalfe and Cooper, 2010; Hutchings et al., 2015; Linehan and Scullion, 2008). Moreover, some of the research has been located in the context of cultural studies/dimensions/values (Adler, 1979; Caligiuri and Tung, 1999; Cole and McNulty, 2011; Cooke, 2014; Harrison and Michailova, 2011).

Such a broad grounding, while sometimes justified, does not allow for the specificity of observations that the literature now needs at its current state of development. Frameworks provide a structure that organizes observations without engaging in prediction. Models, on the other hand, are more specific than frameworks in the sense that they aim at predicting relationships; yet they are less specific than theories that both explain and predict.

Indeed, the studies that have utilized a specific formal theory are in a minority in the female expatriation literature. Among them are Janssens, Cappellen and Zanoni (2006) who used agency theory; Dupuis et al., (2008) who relied on social role theory; Harvey et al. (2009) who applied global dynamic capability theory; and Hutchings et al. (2013) who utilized stereotype theory. Very recently, McPhail et al. (2016) and Fischlmayr and Puchmüller (2016) used social capital theory to investigate, respectively, gay and lesbian expatriates’ issues and female international business travellers' dual career family issues. The core idea of social capital theory, namely that social networks have value, has served as an appropriate lens to examine expatriation issues. We argue that it is more difficult to establish and examine relationships between constructs/concepts if they are not based on a particular theoretical grounding. After all, it is theory that provides both the logic behind these relationships in terms of explaining why certain structures, events, acts, or other outcomes occur or not (Sutton and Straw, 
1995), the boundary conditions within which these relationships are valid, and the vocabulary for analysing these relationships. Theory is “an analytic structure or system that attempts to explain a particular set of empirical phenomena" (Shapira, 2011, p. 1313); it is a device researchers use to imply there is reason and organization within complex empirical work (Bacharach, 1989).

\section{Methodologies}

Interestingly, though the field of female expatriate studies is almost forty years old, comprehensive, systematic literature review papers which chart the history of the field have only been published in the last eight years (Altman and Shortland, 2008, 2011; Salamin and Hanappi, 2014; Shortland, 2009, 2014). Additionally, a number of conceptual articles have appeared with many of them developing propositions or suggesting specific strategies. Examples include Adler (1979; 2002), Altman and Shortland (2001), Caligiuri and Cascio (1998), Caligiuri and Lazarova (2002), Cooke (2014), Gedro (2010), Harris (1995), Harvey et al. (2009), Haslberger et al. (2015), Insch, McIntyre and Napier (2008), and Tharenou (2009). Some of these papers also present models or typologies (e.g., Caligiuri and Cascio, 1998; Caligiuri and Lazarova, 2002). The majority of the literature review papers and conceptual papers have indicated areas warranting future research, some of which have been addressed in subsequent empirical papers.

Within the empirical papers there has been a diversity of methodologies utilised including large sample (above 250 respondents) survey-based research (Adler, 1984a, 1984b; Dupuis et al., 2008; Mäkelä et al., 2011; Paik and Vance, 2002; Selmer and Lauring, 2011; Selmer and Leung, 2002, 2003; Stroh, Varma and Valy-Durbin, 2000; Tharenou, 2006; Traavik and Richardsen, 2010) and relatively smaller sample surveys 
(most with under 100 respondents; Caligiuri and Tung, 1999; Cole and McNulty, 2011; Forster, 1999; Heirsmac, 2015; Hutchings et al., 2008; Hutchings et al., 2010; Lowe, Downes and Kroeck, 1999; Salamin and Davoine, 2015; Shen and Jiang, 2015; Tung, 2004; Varma, Toh and Budhwar, 2006). It should be noted that a number of the studies with smaller sample sizes were conducted with female respondents only and in specific industries or used matched samples, while most of those with larger sample sizes were conducted with both male and female respondents and were done in North America with big numbers of large organizations.

While the female expatriate literature has tended to be dominated by surveybased research it does also include a growing number of papers utilising qualitative research methods. This research has included in-depth interview-based studies of the narrative type (Fischlmayr and Kollinger, 2010; Fischlmayr and Puchmüller, 2016) as well as structured and semi-structured interviews conducted face-to-face, by telephone and more recently by skype (Adler, 1987; Caligiuri et al., 1999; Hutchings et al., 2013; Janssens et al., 2006; Linehan and Scullion, 2008; Linehan et al., 2001; Mathur-Helm, 2002; McPhail et al., 2016; Napier and Taylor, 2002; Roos, 2013; Stalker and Mavin, 2011; Vance and McNulty, 2014). Other studies have used a case study/vignette style (McNulty, 2015), analysis of oral histories (Fisher et al., 2015), context cards and rankings (Harris, 2001), and documentary analysis (Harris and Brewster, 1999). A few studies have utilised mixed methods, combing surveys and interviews (Harrison and Michailova, 2011; Hutchings et al., 2012; Shortland, 2011).

\section{Trends}

The research on female expatriates is almost evenly divided in respect to whether it involves analysis of the views of female expatriates (including repatriates and 
inpatriates) and women managers/employees, or the views of both female and male managers/employees. However, there are clear differences between survey-based and interview-based research in regards to who were the respondents. The majority of survey samples include both men and women and were usually done with managers whereas the majority of the interviews were conducted with females only and were expatriates/repatriates. We speculate that the interview-based research focused more on female-only studies, probably because these studies sought to elicit experiences of actual expatriates and this was achievable given a smaller number of participants needed for qualitative studies. The quantitative studies often seem to be mixed gender samples. This is possibly because they targeted the views of managers to achieve a large response rate and, as men have traditionally dominated in management positions, it may have been much more difficult to access sufficient survey responses for analysis if only women managers were sampled. While a number of papers did not specifically detail the industry context, a majority were conducted across a range of industries. A few papers referred to research being conducted in specific industries/sectors including information technology (Caligiuri and Tung, 1999; Roos, 2013) and oil/gas (Heirsmac, 2015; Shortland, 2011). Where the sector was specified (MNC/for-profit, government, non-government, not-for-profit), an overwhelming majority of studies were conducted specifically with MNCs/Fortune 500/for-profit. Only a few studies specified other sectors including government organizations (Fisher et al., 2015) or mentioned including not-for-profit and NGOs amongst their sample (Harris, 2001; McPhail et al., 2016).

The vast majority of research has studied Western female expatriates or the views of male and female managers/employees in Western countries, primarily North America, the UK, and Western Europe. Exceptions include studies of Chinese female 
expatriates (Shen and Jiang, 2015), East Asian female expatriates (Cooke, 2014), Indian female expatriates (Roos, 2013), Sri Lankan professional women (Hutchings et al., 2015), and Arab professional women (Hutchings et al., 2010; Hutchings et al., 2012). Some studies (Cole and McNulty, 2011; Fischlmayr and Puchmüller, 2016; MathurHelm, 2002; Napier and Taylor, 2002; Paik and Vance, 2002; Salamin and Davoine, 2015) included African, Asian and South American expatriates in their sample, but issues regarding non-Western female expatriates remain under-researched - at least compared to studies on Westerners.

\section{Key Themes in Prior Research}

Altman and Shortland (2008), in their summary of decades of research on women in international management, noted that individual motivation, organizational policies, and host environment experiences were the three dominating themes. These themes essentially drew on Adler's (1984a; 1984b) earlier research into barriers and myths about women's under-representation but the authors also noted how the literature had developed in waves since the 1980s. A year later Shortland (2009) suggested that the continuing low representation of female expatriates can be attributed to four factors: (1) women’s choice; (2) assignee characteristics; (3) social/societal norms; and, (4) institutional aspects.

Building on these observations and findings, but also slightly differing from them, we organize the extant literature into five factors which help to explain the continued under-representation of women expatriates (relative to their male counterparts), namely: (i) perceptions of foreigner prejudice and gender stereotyping; (ii) organizational resistance including selection bias; (iii) women’s own (dis)interest; (iv) support/networks; and, (v) national cultural and social values. While the body of 
literature has debated whether women will suffer foreigner prejudice (and some suggest the perceived prejudice reflects organizational views rather than the reality of host country nationals’ views) the research has consistently reiterated there is organizational resistance to selecting women. Further, while it has been suggested that women may have an interest in international assignments/work/careers, research has also argued that women themselves may be reluctant to apply for, or accept offers of, international work due to family commitments.

Later research also considered whether lack of support for women (e.g., role models, networks) affected women accepting and remaining in international positions. Though this research can be considered as part of the literature on organizational resistance, it could also be argued to constitute a separate area of research which could broadly be categorised as support/networks. Within this area researchers have studied not just limitations on what organizations provide in the form of female role models, mentoring and support, but also positive support female expatriates can access amongst other female expatriates and community networks. Finally, a more recent area of enquiry has examined home country societal and cultural values in respect to expectations towards women to focus primarily on their roles as wives, mothers, and daughters and the impact this may have for women wanting to take assignments and for organizations selecting women. We now consider each of these five themes in turn.

\section{Perceptions of Foreigner Prejudice: Does Gender Stereotyping Occur?}

Adler (1984a; 1984b) explored whether women would not be accepted in international roles due to foreigner prejudice in host countries. Adler (1984a; 1987; 1994) found that women would not experience prejudice in host countries as they would be seen as a foreigner first and woman second and were not viewed or expected to behave in the 
same way as local women. Support for the view that women would not suffer prejudice in host countries came from Caligiuri, Joshi and Lazarova (1999), Stroh et al. (2000), Varma et al. (2006) and Tung (2004). Altman and Shortland (2001) found women may perform well internationally and Selmer and Leung (2003) concluded that women adjusted to the host environment faster than men. Other research supported Adler's (1984a) view that women's visibility and skills may actually be an advantage. For instance, Janssens et al. (2006) found successful women expatriates utilised their gender to create a more empowering identity.

A closer look into the literature reveals some contrasting views. Caligiuri and Tung's (1999) research suggested women expatriates were less cross-culturally adjusted in societies in which there is lower female workforce participation and fewer female managers. Stalker and Mavin (2012) proffered foreign women may have more opportunities than local women but would still experience some gender discrimination in societies in which this was prevalent. Hutchings et al. (2013) argued that while female expatriates may not suffer from discrimination per se, there were some cultural norms to which foreign women were expected to adhere. Similarly, other researchers also highlighted the likelihood that female expatriates would experience gender stereotyping in accordance with local conventions. For instance, Napier and Taylor (2011) pointed out that the local context could affect foreign women’s acceptance. Traavik and Richardsen (2010) maintained women would face barriers as both female and foreigner, and Heirsmac (2015) argued that international assignments would be more challenging for women. Importantly, Lowe et al. (1999) highlighted some women were reticent to work in some foreign locations fearing prejudice. This view was reinforced in recent studies that noted that women in Sri Lanka expected to find 
prejudice (Hutchings et al., 2015) and that some Western women expected prejudice in the Middle East (Hutchings et al., 2013). It can be suggested that if there is foreigner prejudice (or a perception of such), it is not necessarily always held by potential female expatriates (or even host country nationals), but rather may be a view of the management of an organization. This might be deemed to be associated with organizational resistance to select women for international assignments, an issue we address next.

\section{Bias in Selection Processes?}

Adler (1984a; 1984b) examined whether there was a non-supportive corporate attitude which may result in women not being selected for international roles. This suggestion has been consistently affirmed and has focused primarily on bias in selection processes (Harris, 1995; 2001) which may be rather informal. For instance, Harris and Brewster (1999) referred to a 'coffee machine’ selection process in which men are involved in informal discussions about international assignments, but from which women are excluded. Altman and Shortland (2011) suggested that when women lack international experience, this can impact on their ability to reach the highest levels of organizations domestically. This, we contend, implies a kind of 'chicken and egg' situation for women's career advancement. These limitations are further compounded by a continuing perception within some organizations that women will suffer foreigner prejudice if provided with opportunities to work in some international locations.

Further, Adler (2002, p. 756) noted that women continue to be underrepresented in global senior management roles and highlighted a factor as being restrictive managerial styles despite a shift from "wanting women to 'become who they weren't' - men - to encouraging women to 'act as who they are' - women”. Some 
researchers have suggested women face a glass border (Forster, 1999; Linehan and Walsh, 1999) similar to the glass ceiling that affects women’s advancement in domestic organizations and which Insch et al. (2008) refer to as an expatriate glass ceiling. Gedro (2010) further highlighted the existence of a 'lavender' glass ceiling which affects opportunities for lesbian employees specifically and argued there is a 'global closet' which presents challenges for lesbian expatriates including invisibility, discrimination, stigmatization, and safety and security issues. Yet, McPhail et al. (2016) also noted that being lesbian (or gay) may, in fact, be an enabler in expatriation and argued that legal and financial independence within lesbian and gay partnerships may provide greater mobility than for heterosexual couples.

Hutchings et al. (2010) and Hutchings et al. (2012) argued that to counteract trends in selection bias, it is necessary for organizations to proactively support women to advance domestically and into international roles but that in some contexts, such as developing countries in the Middle East, governments also may reinforce organizational initiatives through legislation and education. They further suggested that while Western women have government/legislative support, Arab Middle Eastern women are affected by lack of equal opportunity practices in domestic organizations (despite a governmental emphasis on education and training) and this affects promotion and selection for international roles (Hutchings et al., 2010; Hutchings et al., 2012).

\section{Female (Dis)Interest in International Assignments?}

Adler (1984a; 1984b) considered whether women were disinterested in international assignments. A lack of interest per se has been largely disputed within the literature. It has been consistently noted that work/life balance issues may be an impediment to women undertaking international work (Caliguiri and Cascio, 1998; Fischlmayr and 
Kollinger, 2010; Mäkelä et al., 2011). Thus lack of interest in itself or lack of belief in their own capabilities is not responsible for women not wanting international work; rather it can be seen as too challenging to relocate or travel frequently with children/family commitments (Dupuis et al., 2008; Shortland, 2009).

Further, challenges for dual career couples in sustaining or advancing each partner's career is one of the reasons why women and men may be reluctant to take international assignments (Hippler, 2009). While a range of literature has considered the role of family in supporting or hindering adjustment, recent research (Haslberger et al., 2015) considers family as a unit and has important implications for our understanding of the role of family in assignment decisions. Shaffer and Westman (2015) highlighted that employees who travel frequently to other countries may have disrupted family lives and physical separation between an employee and their family may create more stress for all family members. Mäkelä et al. (2015) found that increased travel days impact on work/family conflict for women with dependent children, although it was also highlighted that though organizations may be reticent to select women, they are more likely to provide them with temporary or frequent flyer international work (MathurHelm, 2002). Research has consistently suggested women with children are more likely to decline opportunities for international work (Stroh et al., 2000; Tharenou, 2009) and Roos (2013) stressed the importance of individual and family resilience in supporting women's international careers. However, single women may also experience conflict between work and family roles (Fischlmayr and Kollinger, 2010) and very few organizations recognize commitments to other family members beyond spouse/partner and children (Haslberger and Brewster, 2008). 
Interestingly, Tharenou (2006) found that women were just as likely as men to self-initiate, often as late career expatriates. Supporting earlier research that work/family balance and work/family conflict are key considerations for women to engage in international careers, it can be surmised that women may be more prepared to take on international work or to consider self-employment internationally when their children reach adulthood as it allows them greater determination in their work hours and responsibilities. Emphasizing differences between women across cultures, Hutchings et al. (2012) noted that new forms of international work (such as domestic jobs with some international travel) may facilitate Western women to engage in global careers, but cautioned that this may be more constraining and result in more work/family conflict for women in the Middle East or Asia where, it has been suggested, women have societal expectations and commitments to extended family (Hutchings et al., 2015).

\section{Support Networks: The Responsibility of Organizations or Expatriates?}

Associated with organizational resistance to selecting women for international assignments is that organizations do not provide sufficient support, mentoring or role models for women to have international careers (Linehan et al., 2001; Linehan and Scullion, 2008; Selmer and Leung, 2002). Salamin and Davoine (2015) advocated that women perceiving that their organization provides adequate support for them to expatriate may enhance their willingness to relocate, whether single or married or having children or not. Harvey and colleagues (2009) affirmed the value of mentoring for female international managers and Caligiuri and Lazarova (2002) advocated that mentoring and networking might also assist with cross-cultural adjustment. This implies that women who do take international work will be more effective if they receive organizational or other support. In contrast, Shortland (2011) argued that if 
organizations provided much-needed female-only networks, there is the risk of promoting male camaraderie in response that could then act at the expense of female inclusion in wider networks. Cole and McNulty (2011) asserted the importance of targeted support by suggesting that levels of self-transcendence could be included in organizations’ selection processes so that those with low scores (whether male or female) can be flagged as potentially requiring more assistance with adjustment prior to undertaking an assignment abroad.

In the absence of organizational support networks many expatriates will seek out other expatriates for advice (Harrison and Michailova, 2011). Yet, Burke and McKeen (1996) argued that female expatriates are less integrated within important expatriate social networks. While men may find collegiality in expatriate communities, women may feel excluded from such networks, as they tend to be male-dominated expatriate groups or activities specifically for trailing spouses and children. Though many female expatriates are married, there are more single female expatriate than single male expatriates (Brookfield Global Relocation Services, 2015); thus they may not benefit in the same way as men from the support and social adjustment which family may offer (Selmer and Leung, 2003; Selmer and Lauring, 2011). Linehan (2000) suggested that given distance from family and friends, formal and informal social networking abroad is more important than it may be in a domestic setting, a view also advocated by Harrison and Michailova (2011). Vance and McNulty (2014) pointed out that social and professional networking is more common for women who self-initiated their expatriation. However, gaining access to male social networks may be the most significant barrier that female expatriates are required to overcome in relation to networking. Indeed this can be a major challenge when women are not interested in the 
sporting/drinking cultures that can be pervasive amongst male expatriate communities (see Hutchings et al., 2008). Given an increasingly tech-savvy world in which individual's rely on information provided on the internet and social media, it might be expected that when women lack sufficient support from their organizations or feel excluded from existing expatriate communities they may benefit from developing their own online and other networks involving expatriates and host country nationals which provide mentoring to females - as well as other types of support.

National Cultural and Social Values: Enforcing Resistance to Women Undertaking

\section{International Assignments?}

An area that has not yet been systematically explored within the literature on female expatriates is the impact of national cultural values (and associated institutional influences) on women's exclusion from, or inclination to engage in, international work. The emerging research within this area has advocated national cultural values and expectations of women's role may lead women and organizations to perceive foreigner prejudice, organizations being resistant to select women, and women having limited interest in international work (Hutchings et al., 2011; Hutchings et al., 2010; Hutchings et al., 2015). Shortland (2009) referred to home country prejudice that she opined might be a barrier to women pursuing expatriate roles in that they expected they might experience difficulties. Paik and Vance (2002) also suggested possible home country prejudice. Hutchings and Michailova (2014) noted that research suggesting tight cultures are negatively related to the emergence of women as leaders might extend to women's engagement in international work in that such cultures are more likely to reflect men’s greater involvement in international careers. 
In their study of Arab Middle Eastern and North American women’s views on global work, Hutchings et al. (2012) proposed that societal and cultural values affected women’s opportunities to travel for work in the Arab Middle East while organizational facilitators for family commitments facilitated North American women undertaking domestic jobs that had some travel components. They found while Western women may not be able to relocate for long-term assignments because of dual career issues, the opportunity to do domestic work with global components may be much simpler if they can access more financial resources and pay for caring responsibilities. This was not deemed acceptable in the Arab Middle East where women would be expected to at least oversee childcare and fulfil expectations of being foremostly a wife and mother (Hutchings et al., 2012). Fischlmayr and Puchmüller (2016) also noted cultural differences in expectations of women who performed frequent international business travel. In a study of Sri Lankan professional women's views of opportunities to undertake international careers, Hutchings et al. (2015) revealed that, like in the Arab Middle East, home country societal values emphasising a primary responsibility of women to family may hinder international opportunities. Their research discovered commitments to parents and extended family in addition to husbands and children meant women felt they should not take international work (and organizations may not select them). This research further indicated the need for an assessment of the role of class and ethnicity (in concert with gender) as affecting international employment opportunities for some women.

FUTURE RESEARCH ISSUES - THEORIES AND FOCI Theoretical Lenses for Examining Female Expatriates 
Social capital theory and role theory have been used in a few studies on female expatriation and we see the further use of such theories as a fertile ground for future research on female expatriates. The existence of social capital is not so dependent on specificities of context; instead it is readily available in the sense that social networks exist and have value in various institutional and cultural environments. This makes social capital theory widely applicable. We also see potential in using social capital theory to examine whether there is a kind of a 'female social capital' that exists more informally.

Role theory, too, seems to be an appropriate choice in the broader framework of female expatriation research. Given much of the research has been occupied with expectations towards, and perceptions of, international assignments, role theory provides a conceptual appeal, a logic and a vocabulary to study those expectations and perceptions. Role theory is also well suited to viewing international assignments as part of more complex and dynamic web including not only expatriates, but also the expectations, objectives, perceptions and preference of local co-workers (host country nationals), superiors, human resource managers and senior executives, as well as other parties such as suppliers, customers, business partners and government officials in the respective host environments.

It would be both relevant and interesting to conduct further studies by utilizing these theories particularly in contexts that are different from the usual areas of enquiry, i.e., extending the research beyond studies primarily focused on for-profit organizations and the views of management, to also examine NGOs and not-for-profit organizations and the views of other stakeholders. The advantage of such a development would be comparing findings and conclusions rather than explaining variation in results by 
attributing them to the variety of theories that have been used to analyse the respective data.

We were somewhat surprised that one of the most influential theories in international business research, namely institutional theory, has not been specifically used to investigate issues related to female expatriation. We see particular potential in studying female expatriates through the lens of the cognitive pillar as one of the three institutional pillars (Scott, 1995; 2005; 2008). Cognitive models represent particular assertions, affirmations or beliefs of individual employees about their reality, thereby allowing employees to assign meaning to their perceptions of the environment and their own actions (Hambrick, 1981; Miles, Snow and Pfeffer, 1974). Cultural-cognitive components accentuate the "shared conceptions that constitute the nature of social reality and the frames through which meaning is made” (Scott, 2008, p. 57). In uncertain environments, such as expatriation, there is a need to perceive and interpret the way others cope with similar uncertainties, and based on such perceptions individuals can be grouped on the basis of cognitive processes. Some of the existing research emphasizes the importance of networks in that sense. Undertaking an assignment in a foreign environment involves dynamic shifts in the conditions in which the expatriate works and lives and affects individual cognition. However, not much is known about these dynamics, thus institutional theory in general, and cognition in particular, can shed new light on the challenges female expatriates face. We see particular value in research utilizing institutional theory and some of its key constructs to better understand the issues female expatriates deal with when expatriating.

Though much of the research on female expatriates has utilized the framework of perceived barriers to women's international career opportunities, interestingly there 
has been little direct engagement with specific gender theories such as social constructivism or post-modernist feminism. Ely and Meyerson (2000) note that gender is the set of social relations through which the categories 'male and female' and 'masculine and feminine' derive meaning and shape experience, and that each is located within specific social, political, and historical conditions and influenced in part by all other social relations, including class, race, ethnicity, nationality, religion, age, and sexual identity. As women may suffer a double (or triple) disadvantage based on their gender and ethnicity (and class) we suggest the value of utilizing gender theory to understand how this disadvantage plays out in women's representation in an international context in respect to women's own choices, home and host country societies' expectations of women's choices, and organizational choices. Such discussions could be undertaken within the context of feminist discourse and in particular black feminism that, while focused on African American women, importantly encapsulates the intersectionality of gender, race and class (Collins, 2015).

\section{Foci for Future Studies}

In addition to the theories which might be used as a basis for future investigations of issues surrounding female expatriates, we also mention here some specific groups of women we suggest need to be more fully considered in future research. The aforementioned stream of research has been extremely beneficial in explicating the reasons why women may not be selected for, or choose (or not) to take up international work in its varying forms as well as the work and non-work challenges which confront them when they do work internationally. However, there is a need for more research to examine why some groups of women remain especially under-represented amongst those who have international careers and what organizations can do to provide more 
inclusive workplaces to facilitate women's international engagement. There is a clear need to consider in greater detail the diversity of women who are working outside their country of origin/residence, the factors that lead to and facilitate their relocation, and the organizational and societal changes they experience.

There are many issues still worthy of examination in relation to female expatriates and expatriation. The list is arguably long, but a few topics include: analyses of how women's motivations to self-initiate expatriation may differ from male selfinitiated expatriates or females who are organizationally-assigned; longitudinal studies of women from developed countries' experiences of adjustment across multiple assignments in other developed or developing countries; and how advanced technology/communication tools can create more opportunities for women to engage in cross-cultural work where cultural values or family responsibilities may make long-term international relocation difficult.

Our analysis suggests that extant research has been overly focused on studies of Western women in dual career couples who are employed by MNCs. Thus, we now focus in detail on three key areas that we recommend future research should address. First, we need to have a greater and deeper understanding of women expatriates from developing countries. Second, we should more fully consider women working in government, NGOs and not-for-profit organizations and in male-dominated industries in for-profit organizations. Third, we ought to further explore issues faced by women in non-traditional family arrangements.

\section{Women Expatriates from Developing Economies}

Salamin and Hanappi (2014) noted that while research until the mid-1990s focused largely on women from North America, it then expanded to Europe with research since 
the 2000s also examining Asia and the Middle East and to a lesser extent Africa. Our analysis suggests while expatriate research has expanded to consider locations we know less about, studies that have actually focused on women from developing economies remain very much in the minority. Though we noted several studies in which female expatriates from developing economies were included in the sample, only a few articles specifically address only women from developing economies. We note that recent research has critiqued the lack of research about South American female expatriates (Harrison, 2014) and Arab women in transnational NGOs (De Vriese, 2014) but there is a need to know more about how many women from developing countries are actually expatriating, what are the obstacles they face in doing so, and what organizational and societal facilitators are required for them to be successful in their assignments. With the two largest countries, China and India, comprising about a third of the world's population, why do we have such limited knowledge of these women's international work experiences?

Moreover, a problem with some of the discussions of female expatriates within international management research is that there is a tendency to use geographic terms (like Asian, Middle Eastern, Western) without sufficient consideration of the vast diversity within these regions. Much of the research about Western women is from North America, the UK, and Western Europe. Yet, the countries within the Anglo cluster have experienced waves of migration that have resulted in multi-ethnic, multicultural societies. So, where is the discussion as to how cultural background or values may impact on a particular woman's experience as an expatriate? When we talk about female expatriates from Asia, we are conflating together a large number of countries that range from industrialised (Japan) to newly industrialising (India) to relatively 
under-developed countries (Bangladesh) and include a vast array of cultures and religions. What implications does this have for how we understand the opportunities that women from these countries have for international careers? Why do we mostly know about women who move from Asian countries to work in low-skilled or domestic service roles in other developing countries and hear close to nothing about the Asian women relocating to lead MNCs and NGOs? Similarly, within the Middle East we find great economic, political and cultural diversity and yet where in the media is the research profiling success stories of women who manage high profile careers and family? Also, why is there such limited research on female expatriates from Central America, South America and Africa? Central and Eastern European women have also had low exposure in research despite strong representation amongst domestic employees and managers. The implication of this dearth of research is that managers and other expatriates do not have sufficient knowledge of how to work effectively with women from a range of national backgrounds or how to use such cultural diversity to their advantage in organizations. For organizations to increase the number of women from varying backgrounds who work in international roles (and to have greater knowledge about the work they do and their challenges) it is critical to provide role models, networking opportunities and to share advice for other women (including potential expatriates).

\section{Women in Government, NGOs and Not-For-Profit Organizations}

Metcalfe et al. (2009) highlighted there is a need to understand international work beyond the corporate world and to consider international development, human rights and social justice roles. Despite some expansion of the issues covered within female expatriate literature since then, the field is still very much focused on women who work 
in MNCs and smaller for-profit businesses. We argue that there is need for a more nuanced understanding of the full range of positions in which women work internationally, including government, NGOs and the not-for-profit sector. Metcalfe et al. (2009) argued that though Arab Middle Eastern women may have limited employment in MNCs, they may benefit from opportunities provided by NGOs and women's professional organizations as well as government agencies responsible for women's issues. Though women may be better represented internationally in not-forprofit and charitable organizations (Hutchings et al., 2010; Shortland, 2009) and some researchers have explored expatriates outside the corporate world (Anderson, 2005; Fisher et al., 2015), there is a need for much more research to specifically understand opportunities for expatriation, cross-cultural challenges, and support mechanisms for female expatriates in these other sectors. We speculate that by the nature of their gender women may have specific needs compared to men in areas of war and civil conflict and that just as women's visibility might be an advantage it could also be a disadvantage in some contexts. Thus, we need to know whether gender stereotyping and expectations to fit with local social and cultural norms for women is more or less prevalent in the noncorporate world.

We also need to establish whether organizations in the non-corporate world are more (or less) willing to select women and to provide support for women to manage work/family balance. Further, within the considerable research done within MNCs many have been industry-wide studies that do not delve into whether barriers and facilitators of women's expatriation are affected by industry type, particularly where there is male-dominance amongst employees. Thus, there is a need for future research to give more consideration to women's experiences working in male-dominated industries 
such as construction, logistics, and energy and resources and to highlight specific practices which organizations implement to facilitate female employees’ international career advancement.

\section{Female Expatriates in Non-Traditional Family Situations}

Our analysis suggests that a large number of studies of female expatriates tend to examine women who are in dual career couples. Even though it has been found there are more single female than single male expatriates, limited analysis has been undertaken of the experiences of single female expatriates. As we pointed out, recent studies have begun to explore women in what might be called non-traditional family arrangements e.g., lesbian expatriates (Gedro, 2010, McNulty, 2015; McPhail et al., 2016), single parents (McNulty, 2015), and single-career couples in which the female is the breadwinner (McNulty, 2014). Yet, we still have very limited knowledge of whether women who are not in dual career heterosexual relationships are under- or wellrepresented amongst expatriates and, if so, why, and what are their actual experiences. We need to know whether women in non-traditional family arrangements are not selected for, excluded from, or choose not to undertake international work because of challenges experienced or lack of/limited support provided by organizations. The literature can also absorb more insights about the views and experiences of: (a) single, divorced and widowed women with or without accompanying children; and, (b) women with accompanying family other than children, including aging parents and other relatives for whom they care including people with disabilities and major health concerns. In order to better understand the needs of this wider diversity of women, researchers need to survey/interview female expatriates as well as their 
spouses/partners, children and other family members to understand cross-cultural stressors, family stressors and required organizational support.

Domestic organizations in many countries have developed policies and practices to accommodate women in differing family situations including flexible work arrangements, child care support, and carers' leave. A justified question is: Are these arrangements also made for female expatriates in non-traditional families? Do women in non-traditional family situations decide not to take international work because it is too difficult? What is the explanation for the limited research on female expatriates outside of those in dual career couples? If they are not sufficiently represented amongst expatriates, is this because organizations have considered it too difficult to support relocation of such women to international contexts? Are there actually increasing numbers of female expatriates in non-traditional family situations who have selfinitiated expatriation but we just do not know about them? There is also a need to consider the types of support that organizations can provide to female women in nontraditional families such as carers for other family members, and providing for children and their nannies to accompany women on international business trips.

\section{CONCLUSION}

For more than four decades female expatriation has been a topic of a vibrant scholarly conversation. The interest in issues experienced by female expatriates and the organizations employing them has been continuous and does not show signs of slowing. Against this background and our analysis of five themes within the literature, we have traced the methodological developments and preferences in the literature on female expatriates. In what we refer to as a more inclusive view of the literature, we sought to extend an examination of the major themes within the literature from highlighting 
contributions and developments in the field to also providing a discussion of the types of female expatriates who have received limited attention in academic publications. Moreover, in analysing major areas of the literature with which the female expatriate research has engaged, we have critiqued the underpinnings of the examined research and speculated as to why some of the existing research has a relatively thin grounding in theory. From this basis we have emphasized the need for more preoccupation with relevant and specified theories in future studies. We have also proposed three particular areas we see as holding promising potential for advancing the scholarly conversation on female expatriation, namely, female expatriates from developing countries, women employed outside of MNCs, and women in non-traditional family arrangements. Though there are emerging studies along these three lines of inquiry, we expect to see more in the coming years.

\section{REFERENCES}

Adler, N.J. (1979), 'Women as androgynous managers: A conceptualization of the potential for American women in international management', International Journal of Intercultural Relations, 3, 407-436.

Adler, N.J. (1984a), 'Women in international management: Where are they', California Management Review, 6, 79-89.

Adler, N.J. (1984b), 'Women do not want international careers: And other myths about international management', Organizational Dynamics, 13 (2), 66-79.

Adler, N.J. (1987), 'Pacific basin managers: A gaijin, not a woman', Human Resource Management, 26, 169-91.

Adler, N.J. (1994), 'Competitive frontiers: Women managing across borders', Journal of Management Development, 13 (2), 24-41.

Adler, N.J. (2002), 'Global managers: No longer men alone’, International Journal of Human Resource Management, 13 (5), 743-760.

Altman, Y. and S. Shortland (2001), 'Women, aliens and international assignments', Women in Management Review, 16 (3), 141-146.

Altman, Y. and S. Shortland (2008), 'Women and international assignments: Taking stock - a 25-year review’, Human Resource Management, 47 (2), 199-216. 
Altman, Y. and S. Shortland (2011), 'What do we really know about corporate career women expatriates’, European Journal of International Management, 5 (3), 209234.

Anderson, B. (2005), 'Expatriate selection: Good management or good luck?', The International Journal of Human Resource Management, 16 (4), 567-583.

Bacharach, S.B. (1989), 'Organizational theories: Some criteria for evaluation', Academy of Management Review, 14 (4), 496-515.

Brookfield Global Relocation Services (2015), Global Relocation Trends Survey Report, Woodridge: Brookfield GRS.

Burke, R.J. and C.A. McKeen (1996), 'Gender effects in mentoring relationships', Journal of Social Behavior and Personality, 11 (5), 91-104.

Caligiuri, P.M. and W.F. Cascio (1998), 'Can we send her there? Maximizing the success of western women on global assignments', Journal of World Business, 33 (4), 394-416.

Caligiuiri, P., A. Joshi and M. Lazarova (1999), 'Factors influencing the adjustment of women on global assignments', The International Journal of Human Resource Management, 10 (2), 163-179.

Caligiuri, P. and M. Lazarova (2002), 'A model for the influence of social interaction and social support on female expatriates cross-cultural adjustment', International Journal of Human Resource Management, 13 (5), 761-772.

Caligiuri, P. and R. Tung (1999), 'Comparing the success of male and female expatriates from a US-based multinational company’, The International Journal of Human Resource Management, 10 (5), 763-782.

Cole, N. and Y. McNulty (2011), 'Why do female expatriates fit-in better than males?: An analysis of self-transcendence and socio-cultural adjustment', Cross Cultural Management: An International Journal, 18 (2), 144-164.

Collins, P.H. (2015), 'Intersectionality’s definitional dilemmas', Annual Review of Sociology, 41, 1-20.

Cooke, Fang L. (2014), 'Women expatriates from East Asia', in Kate Hutchings and Snejina Michailova (ed.), Research Handbook on Women in International Management, London: Edward Elgar, pp.157-185.

Davoine, E., C. Ravasi, X. Salamin and C. Cudré-Mauroux (2013), 'A "dramaturgical" analysis of spouse role enactment in expatriation: An exploratory gender comparative study in the diplomatic and consular field', Journal of Global Mobility, 1 (1), 92-112.

De Vriese, L. (2014), 'Global platforms, local politics: Arab women in transnational organizations', in Kate Hutchings and Snejina Michailova (ed.), Research Handbook on Women in International Management, London: Edward Elgar, pp.121-156.

Dupuis, M-J., V.Y. Haines III and T. Saba (2008), 'Gender, family ties, and international mobility: Cultural distance matters', The International Journal of Human Resource Management, 19 (2), 274-295. 
Ely, R.J., and Meyerson, D.E. (2000), 'Theories of gender in organizations: A new approach to organizational analysis and change', Research in Organizational Behaviour, 22, 103-151.

Fischlmayr, I. and I. Kollinger (2010), 'Work-life balance: A neglected issue among Austrian female expatriates', The International Journal of Human Resource Management, 21 (4), 455-487.

Fischlmayr, I. and K. Puchmüller (2016), 'Married, mom and manager - how can this be combined with an international career?', The International Journal of Human Resource Management, 27 (6), forthcoming.

Fisher, K., K. Hutchings and L.H.F. Pinto (2015), 'Pioneers across war zones: The lived acculturation experiences of US female military expatriates', International Journal of Intercultural Relations, 49, 265-277.

Forster, N. (1999), 'Another glass ceiling?: The experiences of women professionals and managers on international assignments', Gender, Work \& Organization, 6, 79-90.

Gedro, J. (2010), 'The lavender ceiling atop the global closet: Human resource development and lesbian expatriates', Human Resource Development Review, 9 (4), 385-404.

Gunn, N. (2015), 'Women on international assignment: An evolutionary perspective' Expatica, available at http://www.expatica.com/nl/employment/finding-ajob/Women-on-international-assignment-An-evolutionaryperspective_101704.html (accessed 17 August 2015).

Hambrick, D.C. (1981), 'Specialization of environmental scanning activities among upper level executives’, Journal of Management Studies, 18, 299-320.

Harris, H. (1995), ‘Organizational influences on women's career opportunities in international management', Women in Management Review, 10 (3), 26-31.

Harris, H. (2001), 'Researching discrimination in selection for international management assignments: The role of repertory grid technique', Women in Management Review, 16 (3), 118-125.

Harris, H. and C. Brewster (1999), 'The coffee machine system: How international selection really works', The International Journal of Human Resource Management, 10 (3), 459-76.

Harrison, E. (2014), 'Where are the voices from South America?: Argentine, Brazilian and Chilean women in international management”, in Kate Hutchings and Snejina Michailova (ed.), Research Handbook on Women in International Management, London: Edward Elgar, pp.186-216.

Harrison, E. and S. Michailova (2011), 'Working in the Middle East: Western female expatriates' experiences in the United Arab Emirates', The International Journal of Human Resource Management, 23 (4), 625-644.

Harvey, M., N. McIntyre, J. Thompson Heames and M. Moeller (2009), 'Mentoring global female managers in the global marketplace: Traditional, reverse, and reciprocal mentoring', The International Journal of Human Resource Management, 20 (6), 1344-1361. 
Haslberger, A. and C. Brewster (2008), 'The expatriate family: An international perspective', Journal of Managerial Psychology, 23 (3), 324-346.

Haslberger, Arno, Thomas Hippler and Christopher Brewster (2015), 'Another look at family adjustment', in Liisa Mäkelä, and Vesa Suutari (ed.), Work and Family Interface in the International Career Context, Switzerland: Springer, pp.53-70.

Heirsmac, P.T. (2015), 'Influence of personality and gender on expatriate successful assignment in the Nigerian oil and gas industry', Journal of Economics and Development Studies, 3 (1), 239-255.

Hippler, T. (2009), 'Why do they go?: Empirical evidence of employees motives for seeking or accepting relocation', The International Journal of Human Resource Management, 20 (6), 1381-1401.

Hutchings, Kate and Snejina Michailova (2014), 'Women in international management: Reviewing past trends and identifying emerging and future issues', in Kate Hutchings and Snejina Michailova (ed.), Research Handbook on Women in International Management, London: Edward Elgar, pp.3-17.

Hutchings, K., E. French and T. Hatcher (2008), 'Lament of the ignored expatriate: An examination of organizational and social network support for female expatriates in China', Equal Opportunities International, 27 (4), 372-391.

Hutchings, K., P. Lirio and B.D. Metcalfe (2012), 'Gender, globalisation and development: A re-evaluation of the nature of women's global work', The International Journal of Human Resource Management, 23 (9), 1763-1787.

Hutchings, K., B.D. Metcalfe and B. Cooper (2010), ‘Exploring Middle Eastern women's perceptions of barriers to, and facilitators of, international management opportunities', The International Journal of Human Resource Management, 21 (1), 61-83.

Hutchings, K., S. Michailova and E. Harrison (2013), 'Neither ghettoed nor cosmopolitan: A study of western women's perceptions of gender and cultural stereotyping in the United Arab Emirates', Management International Review, 53 (2), 291-318.

Hutchings, K., R. Samaratunge, Y. Lu and A.S. Gamage (2015), “Examining Sri Lankan professional women's perceptions of their opportunities to undertake international careers: Implications for diversity amongst cross-cultural managers”, International Journal of Cross Cultural Management, DOI: $10.1177 / 1470595815611696$

Insch, G.S., N. McIntyre and N.K. Napier (2008), 'The expatriate glass ceiling: The second layer of glass', Journal of Business Ethics, 83, 19-28.

Janssens, M., T. Cappellen and P. Zanoni (2006), 'Successful female expatriates as agents: Positioning oneself through gender, hierarchy, and culture', Journal of World Business, 41 (2), 133-148.

Linehan, M. (2000), Senior Female International Managers: Why So Few?, Vermont: Ashgate Publishing.

Linehan, M. and H. Scullion (2008), 'The development of female global managers: The role of mentoring and networking', Journal of Business Ethics, 83 (1), 29-40. 
Linehan M., H. Scullion and J. Walsh (2001), 'Barriers to women's participation in international management', European Business Review, 13 (1), 10-18.

Lowe, K.B., M. Downes and K.G. Kroeck (1999), 'The impact of gender and location on the willingness to accept overseas assignments', The International Journal of Human Resource Management, 10 (2), 223-234.

Mäkelä, L., B. Bergbom, K. Saarenpää and V. Suutari (2015), 'Work-family conflict faced by international business travellers: Do gender and parental status make a difference?', Journal of Global Mobility, 3 (2), 155-168.

Mäkelä, L., V. Suutari and H. Mayerhofer (2011), 'Lives of female expatriates: Worklife balance concerns', Gender in Management: An International Journal, 26 (4), 256-274.

Mathur-Helm, B. (2002), 'Expatriate women managers: At the cross-roads of success, challenges and career-goals', Women in Management Review, 17 (1), 18-28.

McNulty, Y. (2015), 'Acculturating non-traditional expatriates: A case study of single parent, overseas adoption, split family, and lesbian assignees’, International Journal of Intercultural Relations, 49, 278-293.

McNulty, Y. (2014), 'Women as female breadwinners in non-traditional expatriate families: Status-reversal marriages, single parents, split families and lesbian partnerships”, in Kate Hutchings and Snejina Michailova (ed.), Research Handbook on Women in International Management, London: Edward Elgar, pp.332-366.

McPhail, R., Y. McNulty and K. Hutchings (2016), 'Lesbian and gay expatriation: opportunities, barriers and challenges for global mobility', The International Journal of Human Resource Management, 27 (3), 382-406.

Metcalfe, Beverly D., Kate Hutchings and Brian Cooper (2009), 'Re-examining women's international management opportunities and experiences: A Middle Eastern perspective', in Kevin Ibeh and Sheena Davies (ed.), Contemporary Challenges to International Business, London: Palgrave-Macmillan, pp. 232-250.

Miles, R. E., C. C. Snow and J. Pfeffer (1974), 'Organization-environment: Concepts and issues’, Industrial Relations, 13, 244-264.

Napier, N.K. and S. Taylor (2002), 'Experiences of women professionals abroad: Comparisons across Japan, China and Turkey’, International Journal of Human Resource Management, 13 (5), 837-851.

Paik, Y. and C.M. Vance (2002), 'Evidence of back-home selection bias against US female expatriates', Women in Management Review, 17 (2), 68-79.

Roos, H. (2013), 'In the rhythm of the global market: Female expatriates and mobile careers: A case study of Indian ICT professionals on the Move', Gender, Work \& Organization, 20, 147-57.

Salamin, X. and E. Davoine (2015), 'International adjustment of female vs male business expatriates: A replication study in Switzerland', Journal of Global Mobility, 3 (2), 183-212. 
Salamin, X. and D. Hanappi (2014), 'Women and international assignments: A systematic literature review exploring textual data by correspondence analysis', Journal of Global Mobility, 2 (3), 343-374.

Scott W.R. (1995), Institutions and Organizations, Thousand Oaks, CA: Sage.

Scott W. Richard (2005). 'Institutional theory: Contributing to a theoretical research program', in Ken G. Smith, \& Michael A. Hitt (ed.), Great Minds in Management: The Process of Theory Development, New York: Oxford University Press, pp. 460-484.

Scott W.R. (2008), Institutions and Organizations: Ideas and Interests, Thousand Oaks, CA: Sage.

Selmer, J. and A. Leung (2002), 'Career management issues of female business expatriates’, Career Development International, 7 (6), 348-58.

Selmer, J. and A. Leung (2003), 'International adjustment of female vs male business expatriates', The International Journal of Human Resource Management, 14 (7), 1117-31.

Selmer, J. and J. Lauring (2011), 'Marital status and work outcomes of self-initiated expatriates: Is there a moderating effect of gender'?, Cross Cultural Management: An International Journal, 18 (2), 198-213.

Shaffer, M. and M. Westman (2015), 'Expanding the boundaries of research on global employee families’, Journal of Global Mobility, 3 (2), 102-105

Shapira, Z. (2011), 'I’ve got a theory paper - do you? Conceptual, empirical, and theoretical contributions to knowledge in the organizational sciences', Organization Science, 22 (5), 1312-1321.

Shen, J. and F. Jiang (2015), 'Factors influencing Chinese female expatriates' performance in international assignments', The International Journal of Human Resource Management, 26 (3), 299-315.

Shortland, S. (2009), 'Gender diversity in expatriation: Evaluating theoretical perspectives’, Gender in Management: An International Journal, 24 (5), 365-386.

Shortland, S. (2011), 'Networking: A valuable career intervention for women expatriates?’, Career Development International, 16 (3), 271-292.

Shortland, Susan (2014), 'Women expatriates: A research history', in Kate Hutchings and Snejina Michailova (ed.), Research Handbook on Women in International Management, London: Edward Elgar, pp.18-46.

Stalker, B. and S. Mavin (2011), 'Learning and development experiences of selfinitiated expatriate women in the United Arab Emirates', Human Resource Development International, 14 (3), 273-290.

Stroh, L., A. Varma and S. Valy-Durbin (2000), 'Why are women left at home: Are they unwilling to go on international assignments', Journal of World Business, 35 (3), 241-255

Sutton, R.I. and Straw, B.M. (1995), 'What theory is not', Administrative Science Quarterly, 40 (3), 371-384. 
Tharenou, P. (2006), 'International work in domestic jobs: An individual explanation', The International Journal of Human Resource Management, 16 (4), 475-496.

Tharenou, P. (2009), ‘Women's self-initiated expatriation as a career option and its ethical issues', Journal of Business Ethics, 95, 73-88.

Traavik, L.E.M. and A.M. Richardsen (2010), 'Career success for international professional women in the land of the equal? Evidence from Norway', The International Journal of Human Resource Management, 21 (15), 2798-2812.

Tung, R.L. (2004), ‘Female expatriates: The model global manager?’, Organizational Dynamics, 33 (3), 243-253.

Vance, C. and Y. McNulty (2014), 'Why and how women and men acquire global career experience: A study of American expatriates in Europe’, International Studies of Management and Organization, 44 (2), 34-54.

Varma, A., S.M. Toh and P. Budhwar (2006), 'A new perspective on the female expatriate experience: The role of host country national categorization', Journal of World Business, 41 (2), 112-120. 